\title{
Characteristics of hepatitis $C$ virus infection in HIV-infected people
}

\author{
Curtis L Cooper MD FRCPC, Andrew D Badley MD FRCPC, Jonathan B Angel MD FRCPC
}

CL Cooper, AD Badley, JB Angel. Characteristics of hepatitis C virus infection in HIV-infected people. Can J Infect Dis $2001 ; 12(3): 157-163$.

Knowledge pertaining to hepatitis C virus (HCV)/human immunodeficiency virus (HIV) co-infection is currently incomplete or conflicting. Several points are well studied, however. Plasma HCV RNA levels are higher in matched HIV-infected people than in HIV-seronegative control subjects and are inversely correlated with $\mathrm{CD} 4^{+} \mathrm{T}$ lymphocyte counts. HCV genotype does not appear to influence this value. Co-infected individuals develop histological and clinical features of HCV liver disease more rapidly than HIV-seronegative patients. Co-infected individuals appear to respond to interferon-alpha therapy equally as well as HIV-seronegative HCV-infected adults, but minimal information exists regarding the efficacy and toxicity of combination HCV therapy (interferon-alpha plus ribavirin) in this population. Adverse consequences of highly active antiretroviral therapy in co-infected patients include hepatic toxicity and, in a minority of patients, an 'immune restoration syndrome'. It is unclear whether long term, highly active antiretroviral therapy positively or negatively influences the natural history of HCV infection.

Key Words: Antiretrovirals; HCV; Hepatitis; Hepatitis C virus; HIV; Human immunodeficiency virus

\section{Caractéristiques de l'infection à virus de l'hépatite C chez les personnes porteuses du VIH}

Les connaissances actuelles sur la co-infection à virus de l'hépatite $\mathrm{C}$ (VHC) et à virus du l'immunodéficience humaine (VIH) sont incomplètes et contradictoires. Cependant, plusieurs éléments de la co-infection font l'objet d'études. Ainsi, le taux plasmatique d'ARN du VHC est plus élevé chez les personnes également infectées par le VIH que chez les sujets témoins séronégatifs à l'égard du VIH et il est en corrélation inverse avec le nombre de lymphocytes T CD4. Le génotype du VHC ne semble pas influer sur cette valeur. Les personnes co-infectées présentent des manifestions cliniques et histologiques d'atteinte hépatique plus rapidement que les personnes non porteuses du VIH. Par ailleurs, les patients co-infectés semblent réagir autant au traitement à l'interféron alpha que les patients infectés par le VHC mais non par le VIH; il existe toutefois très peu d'information sur l'efficacité et la toxicité du traitement associant l'interféron alpha à la ribavirine dans ce groupe de patients. Parmi les effets indésirables du traitement antirétroviral hautement actif chez les personnes co-infectées, mentionnons l'hépatotoxicité et, dans une minorité de cas, le syndrome du rétablissement des défenses immunitaires. On ne sait pas encore si l'administration prolongée du traitement antirétroviral hautement actif a une influence positive ou négative sur l'évolution spontanée de l'infection à VHC.

This article is the winner of The Canadian Journal of Infectious Diseases Trainee Review Article Award for 1999-2000 Division of Infectious Diseases, Ottawa Hospital General Campus, Ottawa, Ontario

Correspondence: Dr Curtis L Cooper, Room G12, 501 Smyth Road, Ottawa Hospital General Campus, Ottawa, Ontario K1H 8L6.

Telephone 613-737-8924, fax 613-737-8925, e-mail Ccooper@ottawahospital.on.ca 
$\mathrm{H}^{\mathrm{e}}$ epatitis $\mathrm{C}$ virus (HCV) infects approximately $2 \%$ of the North American population (1); however, within certain high risk groups, including people with hemophilia and intravenous drug users, this prevalence is much higher (2-5). Approximately one-third of human immunodeficency virus (HIV)-infected people are HCV-seropositive (6). Among intravenous drug users with HIV, this rate increases to at least $50 \%$ and up to $90 \%$ in many surveys $(2,5,7)$. Many aspects of $\mathrm{HCV}$ infection and its natural history remain incompletely understood or unstudied. This is also true of $\mathrm{HIV} / \mathrm{HCV}$ co-infection. The present article identifies aspects of $\mathrm{HCV}$ infection in HIV-infected individuals that are well understood and reviews the current knowledge surrounding other relevant, yet unresolved, issues (Table 1).

\section{DIAGNOSIS OF HCV INFECTION}

The diagnosis of HCV infection is based on the detection of immunoglobulin $\mathrm{G}$ antibodies to $\mathrm{HCV}$ envelop, core and nonstructural HCV antigens. Blood specimens are initially screened by enzyme-linked immunoassays (EIA), and positive results are confirmed by the recombinant immunoblot assay. If positive, chronic infection is demonstrated by the detection of plasma HCV RNA by using polymerase chain reaction (PCR) technology. Although first-generation tests have sensitivities as low as 50\%, third-generation kits, which test for multiple antigens, are reported to be highly sensitive and specific in immune competent hosts (8). Diagnosis of $\mathrm{HCV}$ in $\mathrm{HIV} / \mathrm{HCV}$ co-infected patients is more challenging because up to $15 \%$ of patients are negative or indeterminate by EIA despite HCV viremia (9-11). This is, in part, due to assay sensitivity issues as well as HCV antibody seroreversion, a process in which initially positive $\mathrm{HCV}$ antibody measures become negative (12). Newer EIA systems may eliminate both of these problems. In one study, an assessment of an HIV-seropositive cohort by third-generation assay showed greater than $99 \%$ sensitivity and specificity (8). Although these results are impressive, patients at risk but with negative anti-HCV antibody tests by EIA and/or recombinant immunoblot assay should be tested for plasma HCV RNA by PCR assay until additional studies confirm the enhanced sensitivity of newer EIA kits.

\section{HCV VIRAL LOAD}

In immune competent hosts, HCV RNA levels vary greatly among people infected with $\mathrm{HCV}$ and do not correlate with the rate of liver disease progression $(13,14)$; however, they do help predict a patient's response to therapy. The value of $\mathrm{HCV}$ RNA levels in predicting disease progression and response to therapy in $\mathrm{HIV} / \mathrm{HCV}$ co-infected patients is unknown. It is well documented that HCV RNA plasma levels are higher in HIV-co-infected individuals than in HIVseronegative persons with HCV (15-18). This has been demonstrated in studies controlling for age, HIV viral load, $\mathrm{CD}^{+}{ }^{+} \mathrm{T}$ lymphocyte count or other risk factors for HCV progression (18). Several reports reveal a significant inverse correlation between absolute $\mathrm{CD}^{+}{ }^{+} \mathrm{T}$ lymphocyte number and
TABLE 1

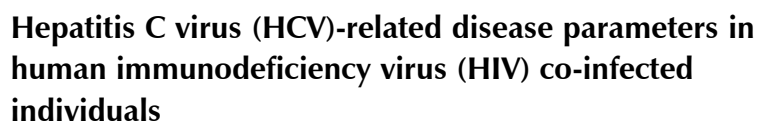

\begin{tabular}{lc}
\hline Parameter & $\begin{array}{c}\text { Observation in HIV co-infection } \\
\text { (compared with HCV infection alone*) }\end{array}$ \\
\hline $\begin{array}{l}\text { Reliability of serology } \\
\text { for screening }\end{array}$ & Decreased \\
HCV viral load & Increased \\
Histiological evidence of & Increased \\
disease on liver biopsy & \\
Rate of fibrosis & Increased \\
Rate of progression to & Increased \\
clinical liver disease & \\
Response to HCV drug therapy & Unresolved \\
Adverse events related to & Unresolved \\
HCV drug therapy & \\
\hline
\end{tabular}

*See text for details

HCV RNA viral load $(18,19)$. In contrast, Mir et al $(20)$ found no correlation between $\mathrm{CD} 4^{+} \mathrm{T}$ lymphocyte count and plasma HCV RNA level. Overall, however, these data suggest that impaired host immunity leads to an elevation in plasma $\mathrm{HCV}$ load. This is further supported by the observation that HCV viral load in chronically infected persons increases following HIV infection (16).

In addition to immune status, CCR $5 \Delta 32$ heterozygosity may influence HCV viral load in co-infected patients (21). Receptor heterozygosity has been associated with slower progression of HIV disease (22). When 16 CCR5 wild-type (WT)/ 332 co-infected patients were compared with 55 CCR5 WT/WT co-infected patients, a significantly lower HCV viral load was found in the former. This group was also more likely to clear spontaneously HCV infection completely (six of 19 [31.6\%] versus nine of 57 [15.7\%]). The CCR5 receptor likely does not directly influence $\mathrm{HCV}$ infection because $\mathrm{HCV}$ does not use this receptor for cell entry. One potential explanation for these findings is that antigen-specific immunity, including that against $\mathrm{HCV}$-specific antigens, is preserved in heterozygous persons because the rate of HIVinduced immune destruction is reduced in this population. This relative preservation of immunity may allow for enhanced control of HCV viral load and greater clearance of $\mathrm{HCV}$ infection.

Other potential predictors of HCV viral load have been assessed. Severity of hepatic insufficiency does not appear relevant to HCV RNA viral load in immune competent hosts (23). Conversely, Dragoni et al (18) demonstrated a significant increase in HCV viral load in HIV-co-infected patients with endstage liver disease compared with those without co-infection (18). This may be explained, however, by lower $\mathrm{CD}^{+}{ }^{+} \mathrm{T}$ cell counts in the former group. As with HIV-seronegative persons, $\mathrm{HCV}$ genotype does not appear to influence viral load in co-infected people $(15,24)$. 


\section{PROGRESSION TO LIVER DISEASE}

Several studies have indicated that HIV infection is an independent risk factor for the presence of liver disease in $\mathrm{HCV}$ infection (25-30). A greater degree of portal, periportal and lobular inflammation, and centrilobular fibrosis has been observed with co-infection $(31,32)$. In another study matched for duration of HCV infection, age, sex, alcohol use and route of infection, core liver biopsies were performed in $54 \mathrm{HIV} / \mathrm{HCV}$ co-infected patients with a median $\mathrm{CD} 4^{+} \mathrm{T}$ lymphocyte count of 320 cells/ $\mu \mathrm{L}$ and were compared with liver biopsies from $53 \mathrm{HCV}$-infected individuals (25). Based on the Metavir Group Histological scale $(30,33)$, perisinusoidal fibrosis in those without portal fibrosis was observed in 10 of 27 (37\%) co-infected patients versus five of 32 (16\%) HIVseronegative people. These results may be relevant because perisinusoidal fibrosis is postulated by some as evidence for early $\mathrm{HCV}$-induced liver disease (25). In patients with $\mathrm{CD} 4^{+} \mathrm{T}$ cell counts below 200 cells/ $\mu \mathrm{L}$, histological evidence of cirrhosis was seen in five of 11 (45\%) compared with six of 58 (10\%) patients with higher $\mathrm{CD}^{+}{ }^{+} \mathrm{T}$ cell counts. These results have been duplicated elsewhere (25), and suggest that both initial and later stage hepatic injury are more common in coinfected individuals. One limitation of these studies is that although approximately two-thirds of co-infected patients were on antiretroviral therapy, details regarding the duration of use and correlation with fibrosis scores were not provided (25). The potential importance of other factors, such as antiretroviral therapy, in explaining the prevalence of liver disease in co-infected individuals is supported by the fact that the three classic histological lesions associated with HCV infection (ie, steatosis, bile-duct injury and lymphoid nodules) were not more frequently identified in co-infected patients (25).

Evidence that HIV infection affects the rate of hepatic fibrosis has been reported (26). In this study, fibrosis progression rates were calculated by dividing Metavir fibrosis stage values by the estimated years of HCV infection. The estimated median duration of $\mathrm{HCV}$ infection before cirrhosis was 26 years (range 22 to 34 years) in co-infected patients versus 38 years for HIV-seronegative people (range 32 to 47 years) and was statistically significant. Furthermore, this study provided additional evidence that impaired immunity (CD4 count less than 200 cells/ $\mu \mathrm{L}$ ) and alcohol consumption greater than $50 \mathrm{~g} /$ week were independently associated with rapid progression to cirrhosis. Sex was not found to be an independent predictor of fibrosis rate.

Lesens et al (34) and Dragoni et al (18) have demonstrated that progression to clinically evident liver disease is also accelerated in co-infected individuals. In the former study (34), 81 co-infected people with hemophilia infected between 1978 and 1985 were assessed for persistent bilirubin elevation greater than $21 \mu \mathrm{mol} / \mathrm{L}$; ultrasound-demonstrated ascites; hepatitic encephalopathy; histological evidence of cirrhosis or hepatocellular carcinoma; and esophageal or gastric varices. Alternative explanations for liver disease, including opportunistic infections, malignancies and alcohol, were ruled out before attributing these end points to $\mathrm{HCV}$ infection. The mean estimated time between $\mathrm{HCV}$ infection and any of these end points was 17.2 years. Twenty-two (27\%) met at least one of these criteria compared with $5.7 \%$ in a matched HCV-infected, HIV-seronegative cohort. Based on this analysis, an odds ratio for progression to these clinical measures of liver disease was 7.4 (95\% CI 2.2 to 22.5). Unfortunately, no attempt was made to correlate antiretroviral use with these hepatic end points. Dragoni et al (18) showed that a low $\mathrm{CD}^{+}{ }^{+} \mathrm{T}$ cell count was correlated with clinical end stage liver disease.

Although the natural history of HCV infection appears to be accelerated in the presence of HIV infection, significant liver disease still requires many years to develop. Rapid deterioration in hepatic status after HIV infection in patients with pre-existing $\mathrm{HCV}$ infection has, however, been described as well (28).

Even in the absence of HIV infection, debate continues as to whether $\mathrm{HCV}$ genotype influences the rate of liver disease progression (35-42). In a study of $119 \mathrm{HIV} / \mathrm{HCV}$ co-infected patients, the clinical course did not differ based on HCV genotype (35). A limitation of this study is that the end points assessed, which included a 30\% decrease in Karnofsky index, $20 \%$ loss of body weight, AIDS-defining illness, death and $50 \%$ or greater fall in $\mathrm{CD}^{+}{ }^{+} \mathrm{T}$ cell count, were more specific to HIV than to HCV-induced end-stage liver disease. Further investigation of this issue is required.

\section{RESPONSE TO ANTI-HCV THERAPY}

Several studies suggest that HIV-infected patients treated with interferon-alpha (INF- $\alpha$ ) for HCV infection have sustained response rates (defined as absence of detectable plasma HCV RNA six months following the completion of INF- $\alpha$ ) that are comparable with those of HIV-uninfected persons (43-45). Sustained response rates of $20 \%$ to $36 \%$ were reported among those participants who competed their course of therapy. Poor responses have been reported in those patients with $\mathrm{CD} 4^{+} \mathrm{T}$ lymphocyte counts below 200 cells/ $\mu \mathrm{L}$ (44-46).

The current standard of care for the treatment of HCV infection in the absence of HIV infection is combination therapy with INF- $\alpha$ and ribavirin $(13,14,47)$. Overall sustained response rates of $40 \%$ to $50 \%$ have been reported; however, this depends on several factors including HCV genotype, plasma RNA level, presence of cirrhosis, age and sex. There are minimal data evaluating this form of therapy in coinfected individuals $(9,48-51)$. At six months, end of treatment response rates of $50 \%$ to $70 \%$ were observed in cohorts of 19,20 and seven co-infected participants, respectively $(9,48,49)$. In another study, all four patients on combination therapy for 12 months were found to have undetectable $\mathrm{HCV}$ viral loads (50). In a study of 18 co-infected patients, 11 were able to complete a six-month course of dual therapy (51). of these, five achieved biochemical and virological sustained responses six months after completing therapy. Drug toxicity was a major factor limiting patient ability to complete combination therapy $(50,51)$. Anemia, related to the use of rib- 
avirin, was a frequently reported serious adverse event (five of $21,23.8 \%$ ), but was successfully managed with dose reduction and/or erythropoetin (50). Other frequently observed adverse events seen in co-infected patients include constitutional symptoms and depressed mood $(50,51)$. It remains unclear whether these side effects are more common in co-infected populations.

\section{EFFECT OF ANTIRETROVIRAL THERAPY ON THE COURSE OF HCV}

Several groups have attempted to identify direct antiviral activity of antiretrovirals on HCV. Neither nucleoside reverse transcriptase inhibitors (NRTIs) $(52,53)$ nor protease inhibitors $(54,55)$ have such an effect. There are no data assessing non-nucleoside reverse transcriptase inhibitor (NNRTI) activity against HCV.

It is unknown whether HCV-induced liver disease progression is affected by antiretroviral therapy. The prevalence of $\mathrm{HCV}$-induced fibrosis in co-infected patients was assessed as a function of antiretroviral use in 122 co-infected patients and compared with 122 matched, HIV-seronegative patients (26). Rates did not differ significantly among patients receiving highly active antiretroviral therapy (HAART) (single protease inhibitor plus double NRTI therapy), double NRTI therapy, single NRTI and no antiretroviral therapy. No patient was on NNRTI therapy. Duration of HAART, double NRTI and single NRTI use was 12.1, 33 and 30 months before liver biopsy, respectively.

As indicated, several studies have described an inverse relation between $\mathrm{CD} 4^{+} \mathrm{T}$ lymphocyte count and plasma $\mathrm{HCV}$ RNA level $(18,19)$. One question that remains is whether an increase in $\mathrm{CD}^{+}{ }^{+} \mathrm{T}$ lymphocyte count after introduction of HAART (56-58) is associated with a reduction in plasma HCV RNA level. At least one study described a reduction in HCV viral load by greater than $0.5 \log _{10}$ at 12 months in seven of 16 patients on HAART with HIV viral loads below 50 copies/ $\mu \mathrm{L}$ (59). In this cohort, HCV viremia became undetectable in four patients. The mean $\mathrm{CD}^{+} \mathrm{T}$ lymphocyte increase at 12 months was $210 \pm 18$ cells $/ \mu \mathrm{L}$. These results suggest that prolonged suppression of HIV replication associated with immunological restoration may result in improved immune control of $\mathrm{HCV}$ infection. This issue remains unresolved, however, because a recent study suggests that HCV viral loads may actually be higher in antiretroviral-treated patients (20). A possible explanation for these seemingly conflicting results, as suggested by Rutschmann et al (54), is that HCV viral load may transiently increase following initiation of HAART as a result of cytotoxic T lymphocyte-mediated lysis of HCV-infected cells, with the release of HCV. After several months, as this process resolves, plasma HCV RNA levels may return to baseline or actually fall below initial levels (60). It may be that only after a prolonged period of time is immunity restored sufficiently to reduce HCV viral load and possibly clear the infection (59).

An 'immune restoration syndrome' has been described after introduction of HAART in co-infected individuals
$(61,62)$. Combination antiretroviral therapy has been highly effective in suppressing HIV viral load with resulting beneficial immunological effects, including increased absolute $(62,63)$ and naive $\mathrm{CD}^{+} \mathrm{T}$ lymphocytes $(64)$, and improved antigen-specific cell-mediated immunity (65). Improved HCVspecific immunity may actually exacerbate HCV-induced transaminitis, induce HCV seroconversion in previously HCVinfected but seronegative individuals, and increase plasma HCV RNA levels (61). Resulting hepatic decompensation and death have been described $(61,66)$. The reason for increased HCV RNA levels and hepatic injury is not fully understood but likely results in part from increased immune-damage to HCV-infected hepatocytes with resulting HCV release (61). Despite the grave consequences of this syndrome, the incidence is low and should not preclude antiretroviral therapy in co-infected individuals.

Unfortunately, both NRTIs (67-69) and protease inhibitors $(70,71)$ have well established hepatic toxicity. These toxicities have negative implications in patients with and without HCV co-infection $(70,72)$. Most studies, but not all (70), suggest that antiretroviral hepatic toxicity is more frequently observed and more severe in co-infected patients $(54,60,72,73)$. Both protease inhibitors and NRTIs were noted to elicit transaminitis in HCV-infected patients newly started on antiretroviral therapy at a frequency almost three times that seen in HCV-negative patients (72). An odds ratio of 6.1 ( $95 \%$ CI 2.2 to 6.7 ) for grade 3 or 4 transaminitis was reported for protease inhibitor use in this study. A recent prospective cohort study raised specific concerns about the use of ritonavir in HCV-infected people (70). A 30\% (95\% CI $17.9 \%$ to $44.6 \%$ ) incidence of grade 3 or 4 elevation in alanine aminotransferase or aspartate aminotransferase was described compared with $8.1 \%$ with other protease inhibitors and $5.7 \%$ (95\% CI, $1.2 \%$ to $12.9 \%$ ) with nucleoside analogue-based therapy. NNRTIs may also be hepatotoxic in co-infected people, but the frequency of this manifestation remains to be established (74).

\section{EFFECT OF HCV ANTIVIRAL THERAPY ON HIV COURSE AND THERAPY}

One concern requiring further investigation relates to the effect of HCV antiviral therapy on the pharmacokinetics and pharmodynamics of antiretroviral agents. Ribavirin, a purine analogue, antagonizes the anti-HIV activity of pyrimidine analogues (zidovudine, ddC, $\mathrm{d} 4 \mathrm{~T}$ ) by inhibiting phosphorylation (75,76). Conversely, ddI (purine analog) levels are increased substantially in vitro by ribavirin (76). The potential in vivo influence of ribavirin on NRTI levels and activity should be considered before initiating HCV therapy in antiretroviral-treated, HIV-infected individuals. The effects of ribavirin on NNRTI and protease inhibitor levels are unknown.

Rapid and irreversible decline in $\mathrm{CD} 4^{+} \mathrm{T}$ lymphocyte count after the use of INF- $\alpha$ has been described in HIV-infected patients $(77,78)$. More frequently, however, a transient decrease occurring between the sixth and 14th week of therapy is observed (77); this is seen in $10 \%$ to $15 \%$ of treated 
patients. This decline is likely evidence of redistribution from the circulating compartment to lymphoid tissue rather than lymphocyte destruction. Despite the effect on $\mathrm{CD}^{+}{ }^{+} \mathrm{T}$ lymphocyte counts, INF- $\alpha$ therapy may be particularly beneficial in co-infected persons based on several studies demonstrating a 1.5 to $2.0 \log$ reduction in HIV viral load with high dose INF- $\alpha$ therapy $(79,80)$. A modest HIV viral load reduction was reported with combination ddI and low dose INF- $\alpha$ (52); however, no clinical benefit was described with this combination therapy or with zidovudine and INF- $\alpha$ (53). Ribavirin also has modest activity against HIV in vitro (81), but a clinical benefit has not been shown (82).

\section{INITIATING HCV THERAPY IN HIV CO-INFECTED PEOPLE}

It is generally accepted that people infected with both $\mathrm{HCV}$ and HIV should not be excluded from drug therapy $(83,84)$. As in HIV-seronegative individuals, therapy should be reserved for those with $\mathrm{HCV}$ virus detected by PCR, sustained alanine aminotransferase greater than 1.5 times baseline, and histiological evidence of necrosis, inflammation or fibrosis on liver biopsy (82). Patients should be clinically stable in terms of both HIV infection and other medical illnesses. Additional contraindications to HCV therapy include psychiatric instability, predicted poor adherence and pregnancy. Patients, if on antiretroviral therapy, should be tolerating these medications well, be adherent to this therapy and have stably suppressed viral load measurements for three to six months while on therapy. HCV drug treatment for individuals not on antiretroviral therapy is reasonable in those with $\mathrm{CD}^{+}{ }^{+} \mathrm{T}$ lymphocyte counts greater than 200 cells $/ \mathrm{mL}$. Given concerns regarding loss of $\mathrm{CD} 4^{+} \mathrm{T}$ cells with INF- $\alpha, \mathrm{HCV}$ therapy should generally be avoided in patients with counts below 200 cells $/ \mathrm{mL}$.

As with HIV-seronegative patients, close clinical and laboratory monitoring is necessary. Given the hematological suppressive effects of ribavirin and INF- $\alpha$, hemoglobin and leukocyte monitoring (including $\mathrm{CD}^{+}{ }^{+} \mathrm{T}$ cells) is vital. Transaminase levels will increase in a large proportion of coinfected patients after the introduction of HCV drug therapy. As long as the patient remains clinically stable and there is no evidence of clinical or biochemical liver function deterioration, it seems reasonable to follow these patients without discontinuing HCV therapy.

Further research is vital before clear, evidence-based guidelines for HCV therapy in HIV co-infected patients can be developed and widely implemented.

\section{SUMMARY}

Much remains to be learned about HCV infection in HIVseropositive persons. The weight of evidence suggests that co-infected people have higher HCV viral loads, develop liver fibrosis more rapidly and present with clinical evidence of cirrhosis sooner than patients infected with $\mathrm{HCV}$ alone. Weakened immunity, as a result of HIV infection, appears to have a permissive role in $\mathrm{HCV}$-mediated liver disease.
Insufficient data are available to determine whether immune restoration following HAART results in improved outcome in terms of HCV-induced disease parameters. Antiretroviral liver toxicity continues to complicate HIV treatment and, in particular, the management of co-infected individuals. $\mathrm{HCV}$ treatment with agents, including INF- $\alpha$ and ribavirin, continues to be assessed in HIV/HCV co-infected patients. These assessments will, it is hoped, result in therapy that is more effective and better tolerated than those regimens currently available.

\section{REFERENCES}

1. Alter MJ. The epidemiology of hepatitis C in the West. Semin Liver Dis 1995;15:5-14.

2. Anand CM, Fonseca K, Walle RP, Powell S, Williams M. Antibody to hepatitis $C$ virus in selected groups of a Canadian urban population. Int J Epidemiol 1992;21:142-5.

3. Quan CM, Krajden M, Grigoriew GA, Salit IE. Hepatitis C virus infection in patients infected with the human immunodeficiency virus. Clin Infect Dis 1993;17:117-9.

4. Scully LJ, Mitchell S, Gill P. Clinical and epidemiologic characteristics of hepatitis C in a gastroenterology/hepatology practice in Ottawa. CMAJ 1993;148:1173-7.

5. Strathdee SA, Patrick DM, Currie SL, et al. Needle exchange is not enough: lessons from the Vancouver injecting drug use study. AIDS 1997;11:F59-65.

6. Stubble L, Soriano V, Antunes F, et al. Hepatitis C in the EuroSIDA Cohort of European HIV-infected patients: prevalence and prognostic value. 12th World AIDS Conference, Geneva, June 28 to July 23, 1998. (Abst 22261)

7. Thomas D, Vlahov D, Solomon L, et al. Correlates of hepatitis $C$ virus infections among drug users. Medicine (Baltimore) 1995,74:212-20.

8. Thio CL, Nolt KR, Astemborski J, Vlahov D, Nelson KE, Thomas DL. Screening for hepatitis C virus in human immunodeficiency virus-infected individuals. J Clin Microbiol 2000;38:575-7.

9. Dietrich D, Weisz K, Goldman D, et al. Interferon and ribavirin therapy for hepatitis $\mathrm{C}$ in HIV-coinfected patients. 39 th Interscience Conference on Antimicrobial Agents and Chemotherapy. San Francisco, September 26 to 29, 1999. (Abst 105)

10. Lok ASF, Chien D, Choo QI, et al. Antibody response to core, envelope, and nonstructural hepatitis $\mathrm{C}$ virus antigens: comparison of immunocompetent and immunosuppressed patients. Hepatology 1993;18:497-502.

11. Barrett L, Gamberg J, Bowmer MI, Nguyen C, Howley C, Grant M. Immunological and virological characteristics of $\mathrm{HCV}$ co-infection in a cohort of HIV-infected individuals. Ninth Annual Canadian Conference on HIV/AIDS Research, Montreal, April 27-30, 2000. (Abst 169)

12. Lefrere JJ, Guiramand S, Lefrere F, et al. Full or partial seroreversion in patients infected by hepatitis $\mathrm{C}$ virus. J Infect Dis 1997;175:316-22.

13. McHutchison JG, Gordon SC, Schiff ER, et al. Interferon $\alpha-2 b$ or in combination with ribavirin as initial treatment for chronic hepatitis C. N Engl J Med 1998;339:1485-92.

14. Poynard T, Marcellin P, Lee SS, et al. Randomized trial of interferon alpha2b plus ribavirin for 48 weeks or for 24 weeks versus interferon alpha2b plus placebo for 48 weeks for treatment of chronic infection with hepatitis $C$ virus. International Hepatitis Interventional Therapy Group. Lancet 1998;352:1426-32.

15. Cribier B, Schmitt C, Rey D, et al. HIV increases hepatitis C viraemia irrespective of hepatitis $C$ viral genotype. Res Virol 1997;148:267-81.

16. Eyster ME, Fried MW, Di Disceglie AM, Goedert JJ. Increasing hepatitis C virus RNA levels in haemophiliacs: relationship to human immunodeficiency virus infection and liver disease. Blood 1994;84:1020-3.

17. Hisada M, O'Brien TR, Rosenberg PS, Goedert JJ. Virus load 
and risk of heterosexual transmission of human immunodeficiency virus and hepatitis $\mathrm{C}$ virus by men with hemophilia. J Infect Dis 2000;181:1475-8.

18. Dragoni F, Cafolla A, Gentile G, et al. HIV-HCV RNA levels and liver failure in coinfected patients with coagulopathy. Haematology 1999;84:525-9.

19. Beld M, Penning M, Lukashow V, et al. Evidence that both HIV and HIV-induced immunodeficiency enhance HCV replication among HCV seroconverters. Virology 1998;244:504-12.

20. Mir J, Fleming C, Steger K, et al. Predictors of detectable hepatitis $\mathrm{C}$ virus RNA (HCV-RNA) levels in HIV+/HCV+ patients. 7 th Conference on Retroviruses and Opportunistic Infections. San Francisco, January 30 to February 2, 2000. (Abs 278)

21. Kaplan MH, Wang XP, Bruckner R, Tetali S, Zhang F, Ginocchio CC. The effect of CCR $5 \Delta 32$ heterozygosity on hepatitis C viral load in HIV-1 infected individuals. 7 th Conference on Retroviruses and Opportunistic Infections. San Francisco, January 30 to February 2, 2000. (Abst 277)

22. De Rosa Husman A, Koot M, Cornelissen M, et al. Association between CCR5 genotype and the clinical course of HIV-1 infection. Ann Intern Med 1997;127:882-90.

23. Nousbaum JB, Pol S, Naples B, et al and the Collaborative Study Group: Hepatitis C virus type Ib (II) infection in France and Italy. Ann Intern Med 1995;122:161-8.

24. Bonacini M, Govindarajan S, Blatt LM, Schmid P, Conrad A, Lindsay KL. Patients co-infected with human immunodeficiency virus and hepatitis $\mathrm{C}$ virus demonstrate higher levels of hepatic HCV RNA. J Viral Hepat 1999;6:203-8

25. Allory Y, Charlotte F, Benhamou Y, Opolon P, Le Charpentier Y, Poynard T. Impact of human immunodeficiency virus infection virus infection on the histological features of chronic hepatitis C: A case-control study. The MULTIVIRC group. Hum Pathol 2000;31:69-74.

26. Benhamou Y, Bochet M, Di Martino V, et al. Liver fibrosis progression in human immunodeficiency virus and hepatitis C virus co-infected patients. Hepatology 1999;30:1054-8.

27. Tefler P, Sabin C, Delvereux H, Scott F, Dusheiko G, Lee C. The progression of $\mathrm{HCV}$-associated liver disease in a cohort of haemophilic patients. Br J Haematol 1994;87:555-61.

28. Eyster ME, Diamondstone LS, Lien JM, et al. Natural history of hepatitis $\mathrm{C}$ virus infection in multitransfused hemophiliacs: effects of coinfection with human immunodeficiency virus. J Acquir Immune Defic Syndr 1993;6:602-10.

29. Soto B, Sanchez-Quijano A, Rodrigo L, et al. HIV infection modifies the nature history of chronic parenterally aquired hepatitis $\mathrm{C}$ with an unusually rapid progression to cirrhosis. A multicenter study on 547 patients. J Hepatol 1997;26:1-5.

30. The French METAVIR Cooperative Study Group. Interobserver and intraobserver variation in liver biopsy interpretation in patients with chronic hepatitis C. Hepatology 1994;20:15-20.

31. Bierhoff E, Fischer HP, Willsch E, et al. Liver histology in patients with concurrent chronic hepatitis C and HIV infection. Virchows Arch 1997;430:271-7.

32. Guido M, Rugge M, Fattovich G, et al. Human immunodeficiency virus infection and hepatitis $C$ pathology. Liver 1994;14:314-9.

33. Bedossa P, Poynard T, for the METAVIR Cooperative Study Group. An algorithm for the grading of activity in chronic hepatitis C. Hepatology 1996;24:289-93.

34. Lesens O, Deschenes M, Steben M, Belanger G, Tsoukas C. Hepatitis $C$ virus is related to progressive liver disease in human immunodeficiency virus-positive hemophiliacs and should be treated as an opportunistic infection. J Infect Dis 1999; 179:1254-8.

35. Piroth L, Bourgeosis C, Dantin S, et al. Hepatitis C virus (HCV) genotype does not appear to be a significant prognostic factor in HIV-HCV-coinfected patients. AIDS 1999;13:523-4.

36. Mihm S, Fayyazi A, Hartmann H, Ramadori G. Analysis of histopathological manifestations of chronic hepatitis $\mathrm{C}$ virus infection with respect to virus genotype. Hepatology 1997;25:735-9.
37. Booth J, Foster G, Levine T, Thomas H, Goldin R. The relationship of histology to genotype in chronic HCV infection. Liver 1997;17:144-51.

38. Garcia-Samaniego J, Soriano V, Castilla J, et al. Influence of hepatitis C virus genotypes and HIV infection on histological severity of chronic hepatitis C. Am J Gastroenterol 1997;92:1130-4.

39. Naoumov N, Chokshi S, Metivier E, Maertens G, Johnson P, Williams R. Hepatitis C virus infection in the development of hepatocellular carinoma in cirrhosis. J Hepatol 1997;27:331-6.

40. Rossini A, Ravaggi A, Agostinelli E, et al. Virological characterization and liver histology in HCV positive subjects with normal and elevated ALT levels. Liver 1997;17:133-8.

41. Poynard T, Bedossa P, Opolon P. Natural history of liver fibrosis progression in patients with chronic hepatitis C. Lancet 1997;349:825-32.

42. Puoti C, Magrini A, Stati T, et al. Clinical, histological, and virological features of hepatitis $\mathrm{C}$ virus carriers with persistently normal and abnormal transaminase levels. Hepatology 1997;26:1393-8.

43. Marriot E, Navas S, del Romero J, Castillo I, Quiroga JA, Carreno V. Treatment with recombinant a-interferon of chronic hepatitis C in anti-HIV-positive patients. J Med Virol 1993;40:107-11.

44. Soriano V, Garcia-Samaniego J, Bravo R, et al. Efficiency of interferon for chronic hepatitis C in HIV+ patients. HIV/IFN/HCV Spanish study group. International Conference on AIDS. August 7 to 12,$1994 ; 10: 220$.

45. Mauss S, Klinker H, Ulmer A, et al. Response to treatment of chronic hepatitis $C$ with interferon $\alpha$ in patients infected with HIV-1 is associated with higher $\mathrm{CD} 4^{+}$cell count. Infection 1998;26:16-9.

46. Soriano V, Garcia-Samaniego J, Bravo R, et al. Interferon alpha for the treatment of chronic hepatitis $\mathrm{C}$ in patients infected with human immunodeficiency virus. Clin Infect Dis 1996;23:585-91.

47. Reichard O, Norkrans G, Fryden A, Branconier JH, Sonnerborg A, Weiland O. Randomized, double-blind, placebo-controlled trial of interferon alpha- $2 \mathrm{~b}$ with and without ribavirin for chronic hepatitis C. The Swedish Study Group. Lancet 1998;351:83-7.

48. Soriano V, Gonzalez J, Perez-Oleda M, Garcia-Samaniego J. Interferon plus ribavirin for chronic hepatitis $\mathrm{C}$ in HIVinfected patients. 12th World AIDS Conference, Geneva, June 28 to July 3, 1998. (Abst 22242)

49. Landau AOL, Batisse D, Duong M, et al. Efficacy of combination therapy with interferon alpha $2 \mathrm{~b}$ and ribavirin for chronic hepatitis C in HIV-infected patients. 39 th Interscience Conference on Antimicrobial Agents and Chemotherapy. San Francisco, September 26 to 29, 1999. (Abst 104)

50. Weisz K, Goldman D, Talal A, Malicdem M, Dieterick D. Interferon (IFN) and ribavirin (RBV) therapy for hepatitis C (HCV) in HIV-coinfected patients. 12-month follow-up. 7 th Conference on Retroviruses and Opportunistic Infections. San Francisco, January 30 to February 2, 2000. (Abst 283)

51. Perez-Olmeda M, Gonzalez J, Garcia-Samaniego J, Arribas J, Pena J, Soriano V. Interferon + ribavirin in HIV + patients with chronic hepatitis C. 7 th Conference on Retroviruses and Opportunistic Infections. San Francisco, January 30 to February 2, 2000. (Abst 284)

52. Kovacs JA, Bechtel C, Davey RT, et al. Combination therapy with didanosine and interferon- $\alpha$ in human immunodeficiency virus-infected patients: results of a phase I/II trial. J Infect Dis 1996;173:840-8.

53. Fernadez-Cruz E, Lang J-M, Jos Frissen PH, et al. Zidovudine plus interferon- $\alpha$ versus zidovudine alone in HIV-infected symptomatic or asymptomatic persons with $\mathrm{CD}^{+}$cell counts $>150 \times 10 \mathrm{E} 6 / \mathrm{L}$ : results of the Zidon trial. AIDS 1995;9:1025-35.

54. Rutschmann OT, Negro F, Hirschel B, Hadengue A, Anwar D, Perrin LH. Impact of treatment with human immunodeficiency virus (HIV) protease inhibitors on hepatitis C viremia in patients coinfected with HIV. J Infect Dis 1998;108:1088-96. 
55. Garcia-Samaniego J, Bravo R, Castilla J, et al. Lack of benefit of protease inhibitors on HCV viremia in HIV-infected patients. J Hepatol 1998;28:526-7.

56. Collier AC, Coombs RW, Schoenfeld DA, et al. Treatment of human immunodeficiency virus infection with saquinavir, zidovudine, and zalcitabine. N Engl J Med 1996;334:1011-8.

57. Hirsh M, Steigbigel R, Staszewski S, et al. A randomized, controlled trial of indinavir, zidovudine, and lamivudine in adults with advanced human immunodeficiency virus type I infection and prior antiretroviral therapy. J Infect Dis 1999;180:659-65.

58. Staszewski S, Morales-Ramirez J, Tashima KT, et al. Efavirenz plus zidovudine and lamivudine, efavirenz plus indinavir, and indinavir plus zidovudine and lamivudine in the treatment of HIV-1 infection in adults. Study 006 Team. N Engl J Med 1999;341:1865-73.

59. Perez-Olmeda M, Garcia-Samaniego J, Soriano V. Hepatitis C viraemia in HIV-HCV co-infected patients having immune restoration with highly active antiretroviral therapy. AIDS 2000;14:212.

60. Vento S, Garofano T, Renzini C, Casali F, Ferraro T, Concia E. Enhancement of hepatitis $C$ virus replication and liver damage in HIV-coinfected patients on antiretroviral therapy. AIDS 1998;12:116-7.

61. John M, Flexman J, French M. Hepatitis C virus-associated hepatitis following treatment of HIV-infected patients with HIV protease inhibitors: an immune restoration disease? AIDS 1998;12:2289-93.

62. Hammer SM, Squires KE, Hughes MD, et al. A controlled trial of two nucleoside analogues plus indinavir in persons with human immunodeficiency virus infection and CD4 cell counts of 20 per cubic millimeter or less. N Engl J Med 1997:337:725-33.

63. Angel JB, Kumar A, Parato K, et al. Improvement in cellmediated immune function during potent anti-human immunodeficiency virus therapy with ritonavir and saquinavir. J Infect Dis 1998;177:898-904.

64. Lederman MM, Connick E, Landay A, et al. Immunologic responses associated with 12 weeks of combination antiretroviral therapy consisting of zidovudine, lamivudine, and ritonavir: results of AIDS Clinical Trial Group Protocol 315. J Infect Dis 1998;178:70-9.

65. Kelleher AD, Carr A, Zaunders J, Cooper DA. Alterations in the response of human immunodeficiency virus (HIV)infected subjects treated with an HIV-specific protease inhibitor, ritonavir. J Infect Dis 1996;173:321-9.

66. Zylberberg H, Pialoux G, Carnot F, Landau A, Brechot C, Pol S. Rapidly evolving hepatitis $C$ virus-related cirrhosis in a human immunodeficiency virus-infected patient receiving triple antiretroviral therapy. Clin Infect Dis 1998;27:1255-8.

67. Lenzo NP, Garas BA, French MA. Hepatic steatosis and lactic acidosis associated with stavudine treatment in a HIV patient: A case report. AIDS 1997;11:1294-6. (Lett)

68. Karras A, Rabian C, Zylbergerg $\mathrm{H}$, et al. Severe anoxic hepatic necrosis in a HIV-1-hepatitis C virus co-infected patient starting antiretroviral triple combination therapy. AIDS 1998;12:827-9. (Lett)

69. Rodriquez-Rosado R, Garcia-Samaniego J, Soriano V.
Hepatotoxicity after introduction of highly active antiretroviral therapy. AIDS 1998;12:1256. (Lett)

70. Sulkowski MS, Thomas DL, Chaisson RE, Moore RD. Hepatotoxicity associated with antiretroviral therapy in adults infected with human immunodeficiency virus and the role of hepatitis $\mathrm{C}$ or B virus infection. JAMA 2000;283:74-80.

71. Brau N, Leaf HL, Wieczorek RL, Margolis DM. Severe hepatitis in three AIDS patients treated with indinavir. Lancet 1997;349:924-5.

72. Saves M, Vandentorren S, Daucourt V, et al. Severe hepatic cytolysis: incidence and risk factors in patients treated by antiretroviral combinations Aquitaine Cohort, France, 1996-1998. AIDS 1999;13:F115-21.

73. Melvin DC, Lee JK, Belsey E, Arnold J, Murphy RL. The impact of co-infection with hepatitis $C$ virus and HIV on the tolerability of antiretroviral therapy. AIDS 2000;14:463-5.

74. Piroth L, Grappin M, Sgro C, Buisson M, Duong M, Chavanet P. Recurrent NNRTI-induced hepatotoxicity in an HIV-HCV-coinfected patient. Ann Pharmacother 2000;34:534-5.

75. Vogt MW, Hartshorn KL, Furman PA, et al. Ribavirin antagonizes the effect of azidothymidine on HIV replication Science 1987;235:1376-9.

76. Baba M, Pauwels R, Balazrani J, Herdewijn P, De Clercq E, Desmyter J. Ribavirin antagonizes inhibitory effects of pyrimidine 2 ', 3 '-dideoxynucleosides but enhances the inhibitory effects of purine $2^{\prime}, 3^{\prime}$-dideoxynucleosides on replication of human immunodeficiency virus in vitro. Antimicrob Agents Chemother 1987;31:1613-7.

77. Soriano V, Bravo R, Garcia-Samaniego J, et al. CD4 ${ }^{+}$ lymphocytes in HIV-infected patients receiving interferon therapy for chronic hepatitis C. AIDS 1994;8:1621-2. (Lett)

78. Vento S, Di Perri G, Cruciani M, Garofano T, Concia E, Bassetti D. Rapid decline of CD4+ cells after IFN $\alpha$ treatment in HIV-1 infection. Lancet 1993;341:958-9.

79. Skillman DR, Malone JL, Decker CF, et al. Phase I trial of Interferon alfa-n3 in early-stage human immunodeficiency virus type I disease: evidence for drug safety, tolerance, and antiviral activity. J Infect Dis 1996;173:1107-14.

80. Frissen PHJ, de Wolf F, Reiss P, et al. High dose interferon- $\alpha 2$ a exerts potent activity against human immunodeficiency virus type I not associated with antitumor activity in subjects with Kaposi's sarcoma. J Infect Dis 1997;176:811-4.

81. Gilbert BE, Knight V. Biochemistry and clinical applications of ribavirin. Antimicrob Agents Chemother 1986;30:201-5.

82. Morsica G, De Bona A, Foppa CU, Sitia G, Finazzi R, Lazzarin A. Ribavirin therapy for chronic hepatitis $\mathrm{C}$ does not modify HIV viral load in HIV-1 postive patients under antiretroviral treatment. AIDS 2000;14:1656-8.

83. National Institutes of Health Consensus Development Conference Panel statement: management of hepatitis C. Hepatology 1997;26:2S-10S.

84. Management guidelines for the HIV and HIV co-infected adult: Recommendations of a nultidisciplinary expert panel. Can J Infect Dis 2001;12(Suppl A):1A-40A. 


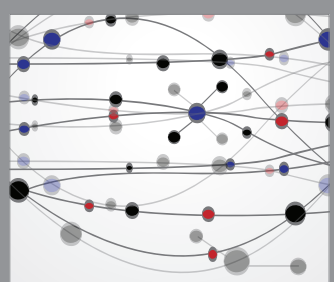

The Scientific World Journal
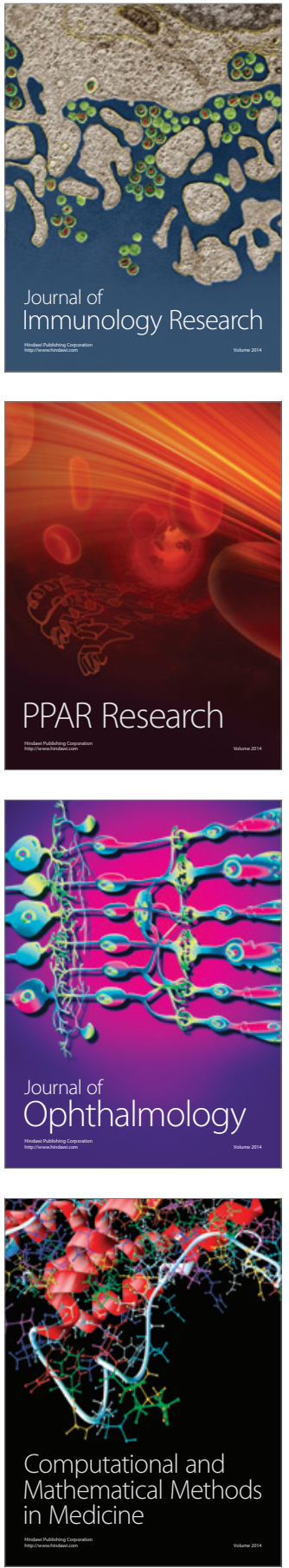

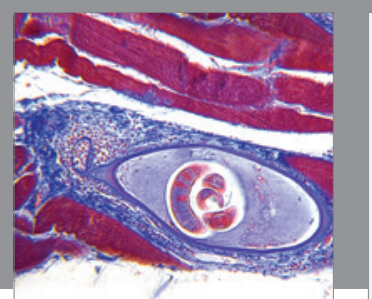

Gastroenterology Research and Practice

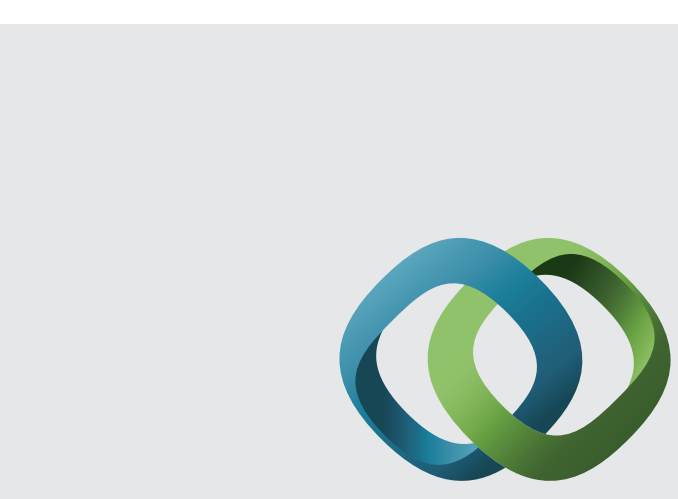

\section{Hindawi}

Submit your manuscripts at

http://www.hindawi.com
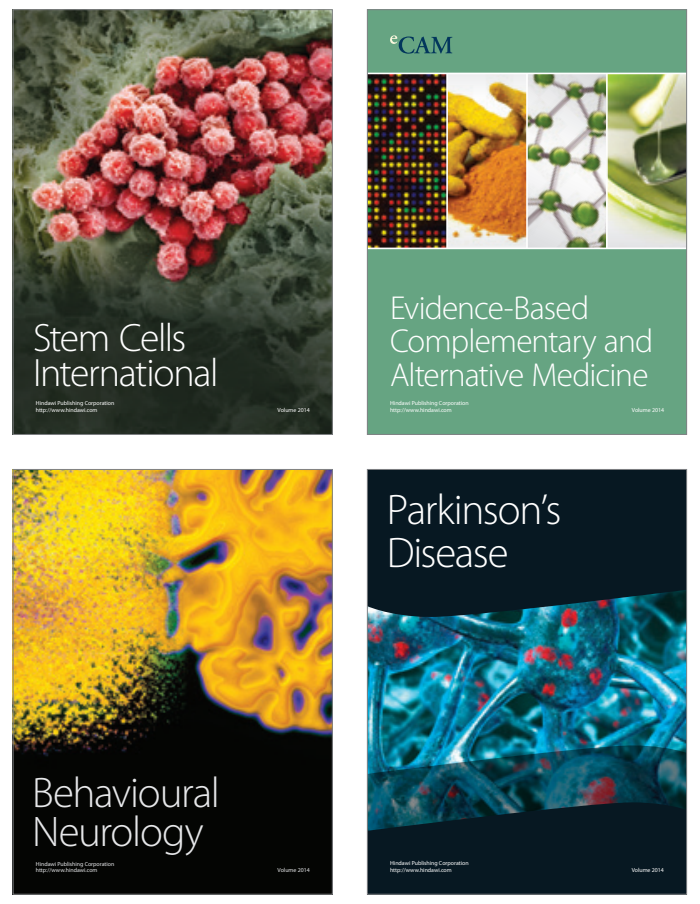
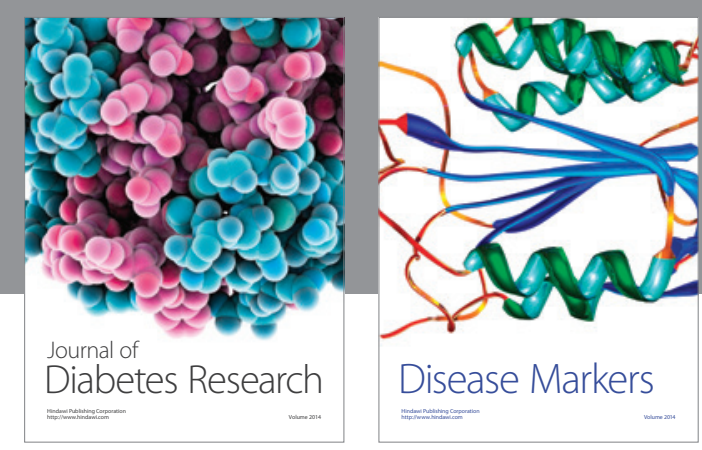

Disease Markers
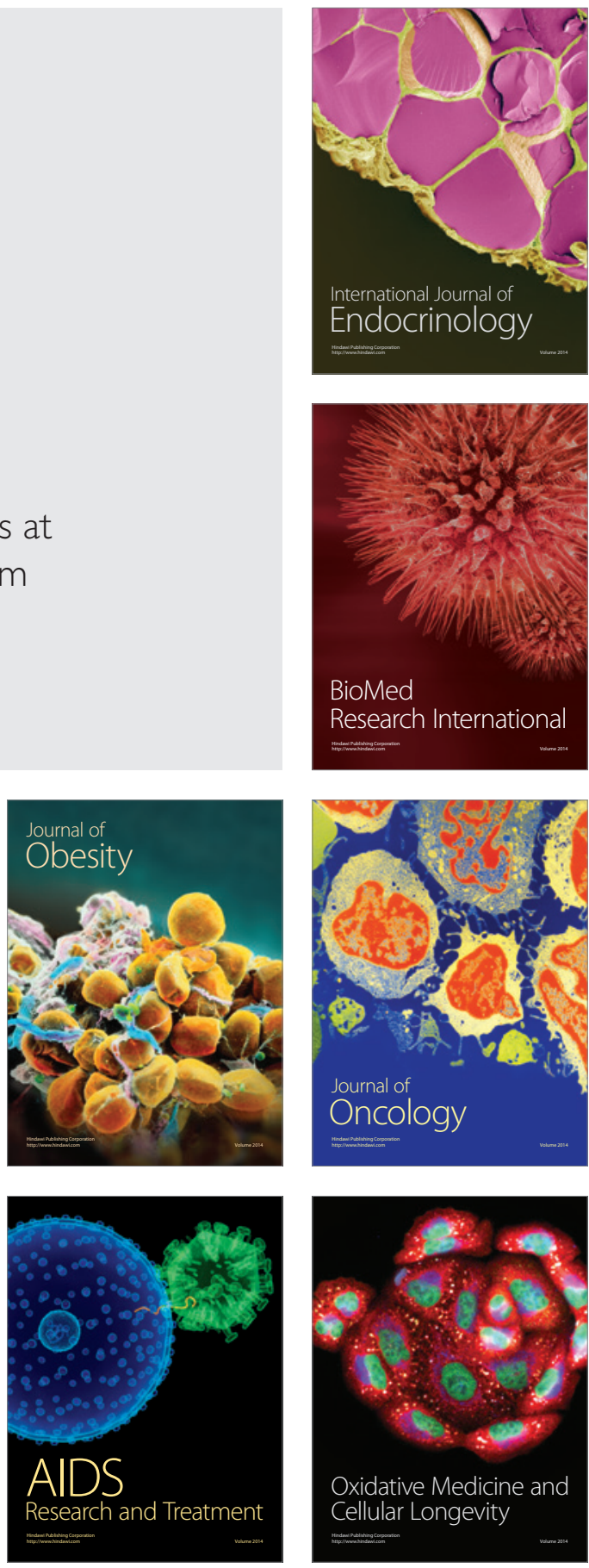